Article

\title{
Cultural Initiatives and Local Development: A Basis for Inclusive Neighborhood Revitalization
}

\author{
Juan-Luis Klein ${ }^{1, *}$, Diane-Gabrielle Tremblay ${ }^{2}$, Laurent Sauvage ${ }^{3}$, Leila Ghaffari ${ }^{3}$ and Wilfredo Angulo ${ }^{3}$ \\ ${ }^{1}$ Department of Geography, Université du Québec à Montréal, Montreal, H3C 3P8, Canada; \\ E-Mail: klein.juan-luis@uqam.ca \\ 2 Ecole des Sciences de l’Administration, Université TÉLUQ, Montreal, H2S 3L5, Canada; \\ E-Mail: diane-gabrielle.tremblay@teluq.ca \\ ${ }^{3}$ PhD Program in Urban Studies, Université du Québec à Montréal, Montreal, H2X 3R9, Canada; E-Mails: \\ laurent.sauvage@teluq.ca (L.S.),ghaffari.leila@courrier.uqam.ca (L.G.), angulo.wilfredo_arturo@courrier.uqam.ca (W.A.) \\ * Corresponding author
}

Submitted: 29 June 2018 | Accepted: 15 August 2018 | Published: 24 January 2019

\begin{abstract}
This article focuses on cultural and creative activities and the development of local communities. Several studies on North America, Europe and Latin America have shown that this type of activity may have a positive impact on the local economy and living environments, and in particular on the sense of territorial belonging and on relations between citizens. In this text, we propose a reading of the impact of neighborhood cultural initiatives in the context of local socio-economic development based on a set of indicators of the local cultural vitality of a neighborhood. The empirical research was carried out in Montreal, namely on two boroughs: Rosemont-La Petite-Patrie and Sud-Ouest.
\end{abstract}

\section{Keywords}

city; culture; local community; local development; Montreal; neighborhood

\section{Issue}

This article is part of the issue "The Transformative Power of Urban Planning through Social Innovation", edited by Torill Nyseth (UiT, The Arctic University of Norway, Norway) and Abdelillah Hamdouch (University of Tours, France).

(C) 2019 by the authors; licensee Cogitatio (Lisbon, Portugal). This article is licensed under a Creative Commons Attribution 4.0 International License (CC BY).

\section{Introduction: The Choice for a Culture of Proximity}

Like other cosmopolitan metropolises around the world, Montreal faces major development challenges in both economic and social terms. However, as has been well established, creative and cultural activities act both as a lever for economic development and as a tool for social development (Martens, Dobbels, Amez, \& Ysebaert, 2014) provided they are part of a broader effort to coordinate between all stakeholders participating in local community development and their actions.

Since the early 2000s, Montreal actors have made the strategic choice of opting for culture, as demonstrated by the slogan "Montréal, métropole culturelle" adopted by the City of Montreal. The development of the Quartier des spectacles in downtown Montreal is part of this orientation (Darchen \& Tremblay, 2013; Lefebvre, 2017). In this article, however, we are interested in another dimension of Montreal's choice for culture. In 2007, the organization Culture Montréal, which brings together the community of creators from the cultural field; the Chantier de l'économie sociale, representing the social economy actors; and the Corporations de développement économique communautaire (community economic development corporations, CDECs) put forward a decentralized cultural strategy, first named Pôles culturels and later Quartiers culturels. This bottom-up strategy (Karsten, 2009) generated broad consensus at the neighborhood level. Local actors rallied around it, including neighborhood round tables (which 
in Montreal are permanent incorporated organizations), other sectoral tables and artists' organizations. They advocate a culture of proximity as well as links to other collective development actions implemented by local social actors.

The culture of proximity is part of an innovative and alternative local development strategy. Traditionally, culture-oriented strategies for urban and economic development have been concentrated and centralized. Inspired by Florida's concept of the creative class (Florida, 2002), these strategies called for massive investments in artistic and cultural amenities and infrastructures to make the city attractive for the so-called creative class that was to stimulate innovation and economic growth. This approach, which prompted many urban governments to invest in prestigious and concentrated cultural assets (Pilati \& Tremblay, 2007), has received much criticism from researchers, who advocated a more inclusive vision of "social emancipation" rather than "physical beautification" (Moulaert, Demuynck, \& Nussbaumer, 2004).

This latter vision calls for a multi-faceted strategy (Tremblay \& Darchen, 2010) oriented to favoring artistic and creative milieus as well as to the interrelation between production, work and cultural life at the neighbourhood level (Klein \& Tremblay, 2016). In addition, it calls for the intervention of local- and community- based organizations as a way to implement "new proximity"oriented social practices (Barbieri, Fina, \& Subirats, 2012 , p. 7). In recent years, more and more cities and metropoles have been interested in this more inclusive perspective of culture and proximity that leads to a more open and distributed vision that is centered neither on the creatives nor on centralized elitist-oriented infrastructures but on the well-being of citizens (Karsten, 2009). Our contribution in this article consists of proposing and documenting a way to reveal and analyze the importance of local cultural vitality in this context.

\section{The Problematic: Creative Activities and the City}

Research on proximity culture in the face of the above-mentioned dominant centralized approach must be linked to the debate on the "new urban policy" (Swyngedouw, Moulaert, \& Rodriguez, 2002) and its orientation toward creative activities. This adjustment is part of an economic revitalization orientation pursued by big cities and metropolises that has been addressed by a considerable number of academic works and provoked strategic debates (Florida, 2002; Markusen, 2008; Mommaas, 2004; Sacco, Blessi, \& Nuccio, 2008; Santagata, 2006; Tremblay \& Tremblay, 2010). These debates focus on policies favoring attractive living environments that can generate prosperity yet are part of a context that questions the means traditionally mobilized by public policies to produce growth.

As several examples have shown, and as mentioned above, urban elites and political actors are turning to culture and the cultural industry (Angulo-Baudin, Klein, \& Tremblay, 2017; Rius \& Sanchez-Belando, 2015; Scott, 2010) and are promoting notions such as the creative city and the creative town (Bianchini \& Landry, 1998; Markusen \& Gadwa, 2010). This choice is part of a broader context that includes the post-Fordist governance of cities and the emergence of territorial marketing as a development strategy (Leriche, Daviet, SibertinBlanc, \& Zuliani, 2008; Sibertin-Blanc, 2009). Seeking to increase their place in the concert of global cities and to foster creativity and innovation, and largely inspired by Richard Florida's concept of the creative class (Florida, 2002), the new urban development strategies promote policies that concentrate cultural activities in order to increase the competitiveness and attractiveness of cities (Scott, 2010), the competitive advantages of central spaces and the profitability of private and public investments made in these areas (Swyngedouw et al., 2002).

These strategies have generated significant criticism regarding their effectiveness as triggers for innovative processes (Peck, 2013; Shearmur, 2010;) as well as their consequences for the residents of the most devitalized cities and boroughs (Chantelot, 2009; Hamdouch \& Depret, 2009; Markusen, 2006a). Even Florida himself eventually came close to recognizing that the creative strategy he had been advocating was ill-guided. According to Wetherell (2017):

Over the last decade, Florida has been beating a retreat away from some of his early optimism.... His latest book, The New Urban Crisis, represents the culmination of this long mea culpa....Florida recognizes that he was wrong. The rise of the creative class in places like New York, London, and San Francisco created economic growth only for the already rich, displacing the poor and working classes.

At the same time, however, the choice for culture gives actors who represent civil society the opportunity to develop more inclusive strategies and is-this is our hypothesis-more effective in terms of increasing a city's attractiveness. Indeed, such strategies have a positive impact: on civic engagement for neighborhoods and for the city as a whole; on the increase of collective capabilities, which have an influence on the social capital of communities (André \& Abreu, 2009; Markusen, 2006b, 2006c); on the construction of positive identities that mobilize citizens (Rius-Ulldemolins \& Posso Jiménez, 2016); and on social cohesion (Moulaert \& Nussbaumer, 2008; Novy, Coimbra, \& Moulaert, 2012). It is this second perspective, which we refer to as the integrated territorial approach of local development by creative and cultural actions, that guides our research. This approach aligns with the integrated area development perspective developed by Moulaert and Nussbaumer (2008) as well as the multiactors and balanced approach asserted by Karsten (2009) and Rantisi (2013). 


\section{Theoretical Approach: Cultural Vitality and Integrated Area Development}

There is a consensus that a deliberate cultural policy will have an impact on the development of communities both in terms of the identity and image it evokes for citizens and of the management and territorial coordination. An important concept for understanding and assessing this impact is that of "cultural vitality", since it is this concept that will trigger the desired socio-economic changes. In a broader sense, "cultural vitality is envisaged by municipal teams as a pull factor for businesses or new inhabitants" (Sibertin-Blanc, 2008, p. 11).

However, is an increase in the competitiveness of cities through the establishment of major cultural events or major cultural infrastructures a guarantor of the overall improvement of the living conditions of citizens in different neighborhoods of the city? Exclusive proposals advocating the centralization of cultural facilities have been contested by a number of authors, who question the effectiveness of such strategies in the actual implementation of innovative territorial development processes (Shearmur, 2010) and who draw our attention to the possible negative impact of policies on the most precarious local communities, who are already weakened by deprivation. By highlighting the dangers of gentrification, the erosion of social relations and the increase of negative identity-based movements, different authors seek to explore new alternatives that underscore the capacity of a culture to bring forth a dynamic that is new, more inclusive and transformative as well as likely to rebuild the social fabric, promote the participation of citizens and restore individual and collective identities (Vivant, 2007).

It is from this perspective that an integrated territorial approach to local development through cultureoriented initiatives emerges with regard to cultural vitality: the new cultural turn among public agencies, which takes place in parallel with the decentralization of cultural facilities, is a prerequisite for the development of a greater culture of proximity. It has been postulated that accessibility to cultural projects and their integration into local development are more effective in terms of attractiveness than large centralized activities; that they stimulate community empowerment (André \& Abreu, 2009; Markusen, 2006b, 2006c); reinforce or generate collective capacities allowing local actors to initiate social innovation (Moulaert, MacCallum, Mehmood, \& Hamdouch, 2013); and promote "the good life" in the city (Novy, 2013).

The convergence of territorial development and proximity culture provides public agencies with a toolkit for ensuring a type of social and economic revitalization favorable to the collective well-being (Roy-Vallex, 2010). It does so insofar as it allows these agencies to rethink the objectives of public policies and to modify the modes of governance so as to involve the residents within the definition, implementation and evaluation of the cultural policy (Auclair, 2011). The link between culture and territory thus refers to a socio-territorial capital that is expressed through the residents' sense of belonging and the constitution of social identities attached to the territory.

\section{Assessing the Cultural Vitality of Neighborhoods: A Performance Scorecard}

In order to equip local actors in their approach to support a culture of proximity, in collaboration with Culture Montréal, we have co-built a set of criteria and indicators as a means to assess the cultural vitality of neighborhoods, the objective of which is to reveal the cultural vitality of neighborhoods and its links with other local community actors as well as to ascertain the organizational and institutional forms taken by the culture of proximity within different neighborhoods in Montreal. ${ }^{1}$ Criteria and indicators are based on research that advocates the integration of cultural activity into territorial development with a view to improving the living conditions of citizens. The set of criteria can be used to empirically observe the cultural vitality of neighborhoods and the place of culture in local development as a whole.

These criteria are the following:

1) Assets: The presence of permanent and ephemeral creative (artistic) and cultural activities, as well as organizations and businesses active in cultural creation in the territory.

2) Leadership: The existence of local leaders and their capability to mobilize and gather a plurality of cultural and artistic resources.

3) Governance: The collective capacity to coordinate and align creative cultural initiatives within the overall set of initiatives aimed at local community development and the ability of a community to orient development towards common goals.

4) Resources: All exogenous and endogenous, financial, organizational, institutional and human resources which cultural and artistic actors as well as other actors are likely to mobilize for the development of arts and culture in the territory.

5) Identity: The existence of positive territorial identities favoring the engagement of local actors and their ability to create social, economic and cultural capital in relation to the local history.

Based on these five criteria, we have worked out 22 indicators that serve to "read" the cultural vitality of neighborhoods (Table 1). Their determination results from various meetings of exchange and validation with the ac-

\footnotetext{
${ }^{1}$ These set of criteria and indicators is a result of collaboration between academic researchers and social actors, in this case, Culture Montréal. This kind of collaboration is supported by the epistemological option of the co-construction of knowledge which implies a paradigm shift in that it allows unofficial knowledge-knowledge of a different cognitive order, co-constructed from diverse knowledge, both academic and practical, and generated, among others, by the stakeholders and actors of innovative initiatives to see the day. See Klein (2017).
} 
Table 1. Criteria and indicators of neighborhood cultural vitality. Source: own compilation.

\begin{tabular}{|c|c|}
\hline Criteria & Indicators \\
\hline Assets & $\begin{array}{l}\text { - Presence of formal and informal places where culture is created, produced and disseminated } \\
\text { - Presence of cultural and artistic events and activities (formal and informal) } \\
\text { - Citizen accessibility }\end{array}$ \\
\hline Leadership & $\begin{array}{l}\text { - Local actors' vision of the role of culture in the community over the long term } \\
\text { - Recognition and legitimacy that benefits actors who mobilize culture } \\
\text { - Rally actors around leaders who work for the well-being of the community } \\
\text { - Sharing of leadership } \\
\text { - Capacity of local actors to include cultural and creative activities in a global development strategy } \\
\text { - Stability and adaptability of leaders } \\
\text { - Efficacy of leadership }\end{array}$ \\
\hline Governance & $\begin{array}{l}\text { - Presence collaborations, joint actions and partnerships favoring the establishment of cultural and } \\
\text { creative activities } \\
\text { - Coordination of local actors having an impact on cultural vitality } \\
\text { - Citizen participation in coordination bodies } \\
\text { - Engagement of cultural actors in the different coordination bodies } \\
\text { - Capacity of cultural actors to rally together }\end{array}$ \\
\hline Resources & $\begin{array}{l}\text { - Presence of creators } \\
\text { - Local cultural entrepreneurship } \\
\text { - Public and private support } \\
\text { - Presence of artistic and cultural know-how } \\
\text { - Citizen engagement in taking part in cultural initiatives }\end{array}$ \\
\hline Identity & $\begin{array}{l}\text { - Sense of belonging and pride of the community } \\
\text { - Presence of cultural carriers and transmitters who reinforce or transmit the sense of belonging }\end{array}$ \\
\hline
\end{tabular}

tors themselves. By involving cultural actors in the definition of cultural vitality indicators and in the design of information collection tools, we have assured ourselves of their validity.

\section{Sites of Observation: The Boroughs Rosemont-La Petite-Patrie and Le Sud-Ouest}

The assessment of the cultural vitality of neighborhoods using the above-mentioned chart was done for two pericentral boroughs of Montreal: Rosemont-La PetitePatrie and Le Sud-Ouest (see Figure 1). The territory of Rosemont-La Petite-Patrie (hereinafter Rosemont) has 139,590 inhabitants and holds $7.2 \%$ of the population of the Agglomeration of Montreal. ${ }^{2}$ Its inhabitants are spread over an area of 15.9 square kilometers. The borough is predominantly French-speaking (83\%) and its population is relatively homogeneous when compared to other boroughs in the city. It includes four neighborhoods, although it is important to distinguish two large zones, that of Rosemont proper, very homogeneous, and that of La Petite-Patrie, more multicultural. The Sud-Ouest borough is inhabited by 78,151 inhabitants, which corresponds to $4.0 \%$ of the agglomeration's population. This borough occupies an area of 15.7 square kilometers and is composed of five neighborhoods whose residents have rather contrasting socio-economic profiles. $^{3}$ The immigrant population is relatively large: almost one resident in two has a direct or indirect immigration background (Figure 1).

These two boroughs have been affected by major economic crises since the 1980s as a consequence of the transformations experienced by all industrial economies (Fontan, Klein, \& Tremblay, 2005). Their story is embedded in the industrialization of Montreal. In Le Sud-Ouest, the presence of the Lachine Canal ${ }^{4}$ and the Grand Trunk Railway (later Canadian National) was the cradle of Canada's industrial revolution and gives evidence to the significant industrial activity that took place there in the late 19th and early 20th centuries (Poitras, 2017).

\footnotetext{
2 The global city of Montreal encompasses the City of Montreal, which includes 19 boroughs with a population of 1,704,694; the Agglomeration of Montreal, which includes the cities located on the Island of Montreal, being the City of Montréal and 14 autonomous cities, with a total population of 1,942,044; and the Montreal Metropolitan Community, which includes 82 autonomous cities, including Montreal, and has 3,932,981 inhabitants. These data correspond to the 2016 census. Source: Ville Montreal (n.d.).

${ }^{3}$ In Montreal, boroughs are administrative units created by the City of Montreal to provide local services and are headed by a borough mayor and a borough council. The neighborhoods, which make up a borough, go back further in history and have been divided up, in part, through zoning by the City for the purpose of facilitating the management of housing.

4 The Lachine Canal was built in 1825 to circumvent the Lachine Rapids and to extend navigation on the St. Lawrence River upstream toward the Great Lakes. It was enlarged in the second half of the 20th century in order to adapt to the needs of navigation. In 1970, it was closed to commercial navigation, which had turned to using the St. Lawrence Seaway, a new route more suited to the size of modern ships. In 2002, it was reopened for pleasure boating.
} 


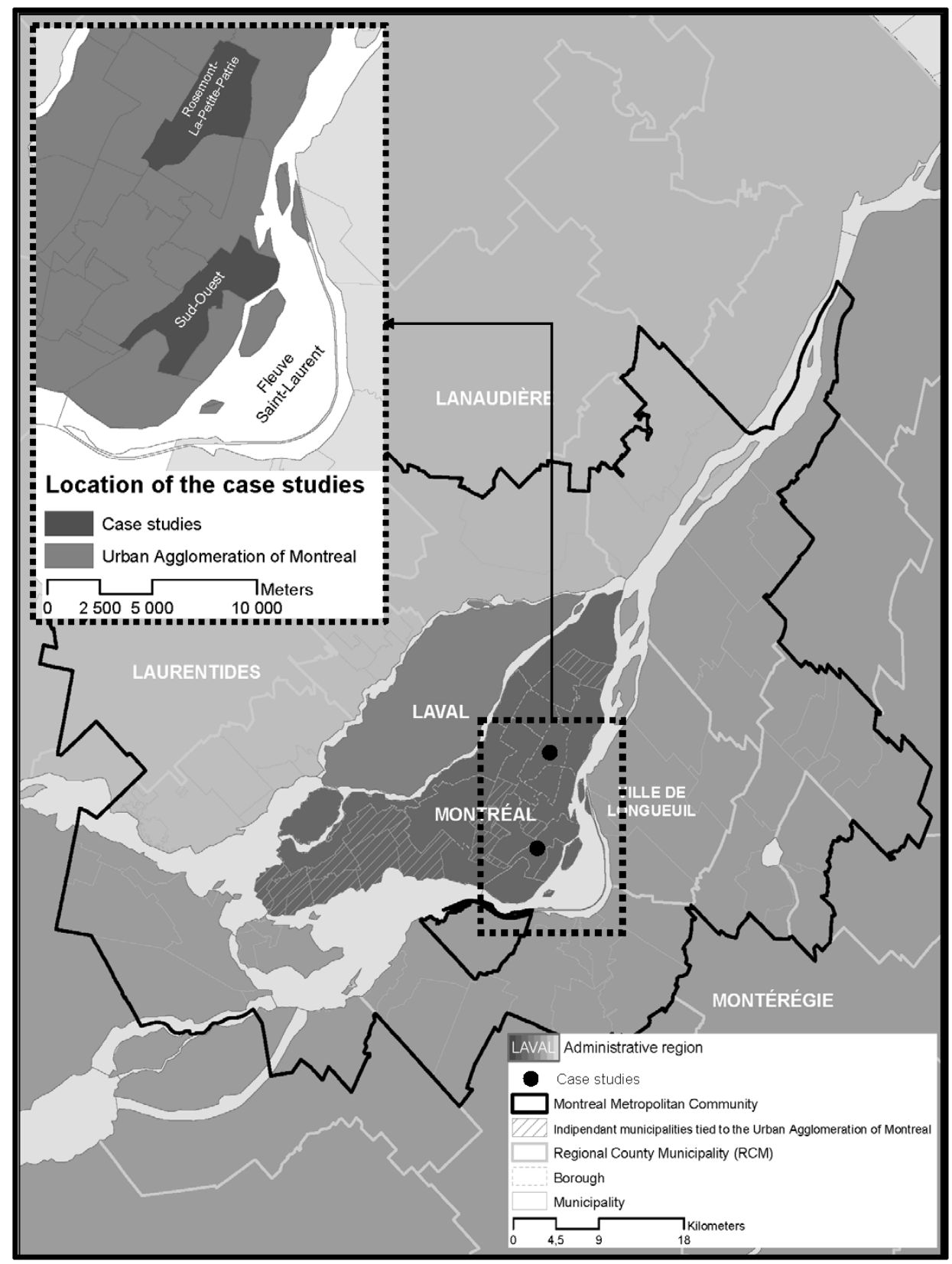

Figure 1. Case studies in Montreal. Source: own production.

Rosemont, for its part, experienced strong industrial growth in the early 20th century due to the presence of the Canadian Pacific Railway company and Ateliers Angus (established by Canadian Pacific Railway), which manufactured locomotives and railroad cars (Nadeau, 2009). The industrialization of these neighborhoods thus explains the strong presence of a working class-and also explains their disarray ${ }^{5}$ during the crisis of Fordism and the industrial redeployment of the 1980s.

These two boroughs then lost part of their productive base, which affected local services and the quality of life of citizens. However, in both boroughs, the communities mobilized and, in the 1980s, the above- mentioned CDECs were created with the mission of rallying the actors in order to counteract the loss of productive assets and to create jobs. In Rosemont, the CDEC was a main catalyst of the Technopôle Angus project, which has become a driver of social innovation and job creation in the territory. In the Sud-Ouest, the CDEC, then named Regroupement économique et social du Sud-Ouest (RESO), gave rise to a number of diverse social economy projects. It should be noted that this borough has the Lachine Canal, which, since its reopening for leisure purposes in the early 2000s, has been a driving force in the revitalization of the borough that is gradually becoming attractive as a residential area.

\footnotetext{
${ }^{5}$ We employ "disarray" in the sense given to this word by Pinçon (1987) in his book on the workers' disarray (désarroi in French) caused by the closures of economic activities.
} 
Thus, following many years of economic decline, these two boroughs, from the 2000s on, engaged in revitalization processes that profoundly transformed some of its parts, both physically and socially (Klein \& Shearmur, 2017). Both boroughs underwent gentrification processes, although with different consequences. While the profile of the population is stable in Rosemont, it is changing in the Sud-Ouest with the arrival of a contingent of residents with higher incomes. In addition, since the 2000s, the community organizations of the neighborhoods that make up these boroughs have implemented various projects involving cultural activities. These initiatives often combine the objectives targeted by local economic development with those of cultural development. In fact, both territories are marked by a strong cultural effervescence. It is this common characteristic between these two boroughs that led us to choose them for our empirical study.

\section{Methodology}

Field research was conducted in the boroughs Rosemont and Sud-Ouest using the multi-site case study method (for the multi-site case study method see Yin, 2009; see also Crowe et al., 2011). Our objective in applying this method was not so much to compare the two boroughs in question as to use the knowledge of their differences to arrive at an expanded reading of local cultural vitality based on the criteria and indicators presented previously. For this, we conducted semidirected interviews in each borough, whereby we sought to have an adequate territorial representation with regard to not only the neighborhoods that comprise the boroughs but also, at a more functional level, the different types of local actors engaged in the creative activities. Respondents were selected using the purposeful sampling method. The interviews were conducted using an interview guide developed from themes that encapsulate the above-mentioned indicators gathered under five topics (Creative assets, leadership, governance, resources, identity).

In Rosemont, 19 semi-directed interviews were conducted between June and August 2016. The interviews focused on the entire borough and on three of the borough's four neighborhoods (Saint-Édouard, better known as La Petite-Patrie, Étienne Desmarteau and Vieux-Rosemont) in which the vast majority of the borough's cultural activities take place. In the Sud-Ouest, which, as we shall see, is more complex, 28 interviews were required in order to apprehend the different dimensions of the borough's cultural vitality. These interviews were conducted between May and November 2017. They focused on the borough as a whole as well as on the five neighborhoods that comprise it (Griffintown, Petite-Bourgogne, Saint-Henri, Pointe-Saint-Charles and Saint-Paul-Ville-Émard; see Table 2). Each interview was partially transcribed, and the relevant information was coded in an excel table built on the themes listed above to have a general view of each indicator.

\subsection{The Results of the Study: A Portrait of the Local Cultural Vitality}

The study of the boroughs of Rosemont and the SudOuest allowed us to offer a general overview of these two boroughs based on the actors' assessment of the cultural vitality of their neighborhoods and of the assets needed to enhance it. The overview was established based on information obtained on the cultural organizations present in the boroughs and the interviews conducted. It is presented using the set of criteria and indicators as featured in Table 1.

\subsubsection{Assets: Presence of Artistic and Cultural Activities}

The cultural events taking place in the two boroughs reveal two approaches. The Sud-Ouest hosts either crowdpleasing events with a reach throughout Montreal and beyond, in particular festivals, or else activities targeting direct contact between the creators and the residents. In Rosemont, by contrast, the events are lighter and more aligned to the cultural offer desired by the local residents, as underlined by a community organization representative: "There are many small initiatives and many spontaneous developments and small events that we aren't aware of, but that people hear about, and will participate in" (personal communication, community organization, Rosemont).

The spatial distribution of cultural venues is also very different in the two territories studied. In Rosemont, where activities target the entire borough, these places are concentrated in the western part of the borough, in the Petite-Patrie and Vieux-Rosemont neighborhoods. Among the infrastructures that contribute to this centrality is Cinéma Beaubien, a social economy enterprise whose development since the 2000s is indebted to com-

Table 2. Respondents by type and territory. Source: own compilation.

\begin{tabular}{lcrr}
\hline Type of Respondent & Rosemont & Sud-Ouest & Total \\
\hline Culture and artist organization & 11 & 14 & 25 \\
Socio-economic development organization & 3 & 5 & 7 \\
Community organization & 2 & 7 & 9 \\
Municipal administration & 3 & 2 & 5 \\
Total & 19 & 28 & 47 \\
\hline
\end{tabular}


munity action and, in particular, to the local CDEC. In this borough, the community movement has invested in the cultural field, with Cinéma Beaubien being one of its great accomplishments. In the Sud-Ouest, cultural activity is distributed more evenly across the different neighborhoods of the borough. The Lachine Canal, on the banks of which a number of cultural events take place, especially during the summer, functions as a link between the different neighborhoods. The distribution of municipal facilities across the neighborhoods ensures a specific cultural offer in each neighborhood.

Whether in the Sud-Ouest or Rosemont, respondents emphasize the positive effects of creative and cultural activities for the quality of life of residents. In this way, these activities constitute a social glue and an important economic lever. Also, for the commercial actors, culture enhances their customer traffic, promotes the attraction of new customers and brings about important commercial spin-offs. In the words of one respondent:

People come from all over to see our shows. Our last vernissage drew some 300 people. This generates business for merchants with street-level stores. People come and consume and buy things in those smaller stores and shops. (personal communication, cultural and artist organization, Rosemont)

\subsubsection{Leadership: The Capacity to Mobilize Actors and Resources}

Two types of leadership can be distinguished. In Rosemont, the role of the Regroupement Arts et Culture Rosemont-La Petite-Patrie (RACRPP) is to be emphasized. Founded in 2006, this organization's mission is to "bring together people and organizations who work professionally in the field of arts and culture in RosemontPetite-Patrie to participate in the development of the cultural life of this borough" (RACRPP, 2018). This mission includes creating links with political and administrative authorities and promoting networking as well as the exchange between artists and the community. Most respondents agree that RACRPP's leadership is essential for the cultural life in Rosemont. The organization federates a large number of cultural actors and embodies a type of leadership that is recognized by the cultural community. The municipal administration's consideration of the role played by the RACRPP is reflected in the existence of a dialogue that is built around shared values, such as importance of cultural mediation, citizen involvement and cultural information.

Based on my participation at the Rosemont-PetitePatrie round table on culture, I believe that this vision of culture is shared. Even among the politicians who are part of this table there is a climate of agreement as regards core ideas and fundamental principles like cultural mediation, the importance of involving citizens in culture as well as, more recently, the impor- tance of communicating information about cultural events. (Personal communication, socio-economic development organization, Rosemont)

The collective leadership exercised by the RACRPP is exemplary. However, a number of respondents fear an exhaustion of sorts among the main leaders in the cultural arena, which could possibly result from the decrease of resources following neoliberal austerity measures implemented by the government and municipal administration over recent years.

In the Sud-Ouest, the leadership is more fragmented. While difficult to ascertain at the borough level, it is clearly observable once analyzed on a smaller scale, that of the neighborhood. The cultural policy developed by the political actors at the neighborhood level was appropriated neither by the creators nor by the socioeconomic actors. Among the reasons that may explain this situation is, to begin, the fragmentation of the territory: the cultural dynamics are very clearly inscribed in neighborhoods and spread throughout the borough only on rare occasions. Secondly, we are witnessing a reconfiguration of the cultural milieu of the Sud-Ouest that is triggered by two factors: the rapid socio-economic transformations of certain areas of this neighborhood; and the transformation of the mandate of the local CDEC, which is RESO. This organization had set up a table and regular meetings of cultural leaders at the borough level. Although it failed to build up the desired momentum, it did allow for the coordination of cultural actors and embedded the role of culture in the strategic actions of local development-especially in the Plans d'Action Locale pour l'Économie et l'Emploi, which are local economy and employment action plans. Over time, the organization has constructed a vision in which culture is a key element in the reconversion and development of the district. It has rallied the economic, political and community actors around this vision by eliminating some resistance.

The local people made a point of saying that culture as a driver of development was one of their main priorities. But to assert this, [it] calls for a vision, which I believe came largely from the artists who had been investing in the old industrial complexes, and which had become a reality that could no longer be denied. They asserted that they weren't content to just take advantage of the decline and wanted to participate in revitalization as well. So that is where the question of the role of culture in revitalization came up. And I remember the community group was somewhat reserved, if not worried or skeptical, in the face of cultural issues. It seemed to think that putting energy into culture would take away resources from the more essential community challenges, such as food, housing, clothing and education. But over time, the community sector became an ally in culture. (Personal communication, socio-economic development organization, Sud-Ouest). 
The round table did not survive the RESO transformation that followed the decrease in funding caused by the implementation in 2015 of government austerity policies. The end of such coordinating activities in addition to geographic constraints meant that the traditional inclination of the Sud-Ouest actors to confine themselves to their neighborhood was reinforced, which has favored the emergence of a localized leadership performed by individuals at the head of organizations or events (Théâtre Paradoxe, la Maison de la Culture Marie-Uguay, Film Noir sur le Canal).

We observe that the leadership applied in Rosemont is performed by leaders and organizations who coordinate the cultural offer at the borough level and who act in alignment with the borough council. In the Sud-Ouest, this coordination no longer exists, especially since the cultural round table has disappeared. In that context, cultural businesses in the Sud-Ouest have become detached from the borough's socio-economic actors, applying their leadership either in specific neighborhoods only or else with a perspective that goes beyond the borough, such as by targeting clients from outside the borough.

\subsubsection{Governance: Ways of Coordinating Actors and Initiatives}

This theme focuses on the evaluation of how creative cultural initiatives are linked with the entirety of initiatives aimed at local community development, that is to say, the capacity of a community to orient development towards common goals. As we have seen in Rosemont, the cultural actors have set up a table for coordination which, according to the majority of respondents, has a structuring role for the culture in the borough. The RACRPP, which operated in close collaboration with the CDEC RPP until the closure of the latter in 2015, thus demonstrates, as we have already underlined, the capability to bring together cultural, economic and political actors of the territory. It appears that the cultural and community sectors in Rosemont are consolidated through strong ties and bonds. In the words of one municipal actor:

Rosemont has integrated culture into the community sector: in the old part of Rosemont, the community movement has developed cultural venues and events at the local level. This kind of cultural activity distinguishes it from the more urban core. (personal communication, municipal administration, Rosemont)

In the Sud-Ouest, the Table des acteurs culturels du SudOuest (table of Sud-Ouest cultural actors), created by RESO (the local CDEC), played a similar role according to a number of respondents. The following quote summarizes their appreciation:

All the initiatives that emerged and that had a chance of being operational and viable were supported by RESO....In 1997, there was first the creation of the ta- ble of cultural actors. This was the first real intervention of RESO that was structured to bring together the cultural actors of the borough and to start and see what the cultural development issues were; not necessarily the cultural offer, but rather culture in the sense of something to reappropriate in the context of a neighborhood undergoing redevelopment. So, it was more the idea of culture as a factor of revitalization, and a factor of societal growth for the population. (personal communication, municipal administration, Sud-Ouest)

The role of the CDECs has thus been crucial for the structuring of the local arts and cultural sector. The decision of both the provincial government and city hall to strip these organizations of their financial resources, which led to the closure of the CDEC RPP and the weakening of RESO, had consequences, especially in the Sud-Ouest. As mentioned, the table of cultural actors of the Sud-Ouest folded, which deprived the territory of an agency dedicated to coordinating the cultural actors.

In both boroughs, the interviews revealed the existence of a certain number of more localized coordination efforts around creative and cultural projects. In Rosemont, for example, commercial development companies and retailers' associations provide for networking and exchanges between local businesses, cultural organizations and artists. This web of interactions appears to contribute to the vitality and local cultural dynamics. Many cafes offer their spaces to hold exhibitions and concerts. These interrelations make it possible to transcend the competitive dynamics inherent in commercial activity, in turn allowing for a collaborative dynamic to take root. In the Sud-Ouest, there is an overlap in the dynamics concerning the coordination of projects on the one hand and the issues targeted by cultural leaders on the other. It is mainly the neighborhoods that serve as a framework for these coordination efforts. However, the cultural activities set up around the Lachine Canal make it possible to transcend these neighborhood-based dynamics in favor of a coordination done at a larger scale and that establishes links between diverse actors: cultural actors, borough council, Parks Canada, Quartier de l'Innovation, Société de développement commercial, etc.

\subsubsection{Resources: The Means Accessible to Creators}

This theme concerns the means (financial, organizational, institutional and human) which cultural and artistic actors as well as other actors mobilize for the development of arts and culture in the territory. In Rosemont, artists rely on the collaboration of the commercial sector, the cafes for example, which serve as meeting points for the artistic community living in the area as well as, in some cases, venues of creation. These sites of creation and dissemination give artists and cultural creators the opportunity to build mutual support networks and to 
establish informal as well as more formalized collaborations with one another. This can take the form of sharing equipment, work spaces and know-how.

In the two boroughs, most of the artists and cultural actors met claim feeling a strong territorial rootedness and are eager to participate in the cultural vitality of their neighborhood, and some even aspire to leave a lasting mark, in a work of public art for example. The respondents mentioned that several well-known artists reside in their territory and that these maintain strong bonds with the citizens. In the case of Rosemont, with reference to this commitment of artists to their community, one respondent said: "They have Rosemont tattooed on their heart" (personal communication, socio-economic development organization, Rosemont).

One important aspect in terms of resources is public support, particularly through the borough council, which respondents view as very important. This support may translate into help with the establishment of cultural organizations, the granting of a free lease, the promotion of certain organizations, the hiring of local artists for public events, and help with administrative procedures. "In the projects that I initiated, the municipality provided immense logistical support", said one respondent (personal communication, cultural and artist organization, Sud-Ouest).

Social entrepreneurship, represented by the Société de développement Angus in Rosemont and the Quartier de I'Innovation in the Sud-Ouest, are identified as organizations that support the role of culture in improving the quality of citizens' lives. These two organizations constitute milestones in the advancement, at the level of their borough, of innovation ecosystems in which cultural actors have an important place.

Finally, the role of Sociétés de Développement Commercial (commercial development corporations, SDCs) in supporting local cultural initiatives should be emphasized, in both boroughs. In Rosemont as well as in the Sud-Ouest, their support is vital for the organization of events in the neighborhoods or commercial arteries. They contribute with funding to the realization of a number of activities: "The SDCs support culture a lot....They are important levers. They are funded by its members and have set up programs to finance certain events" (personal communication, socio-economic organisation, Rosemont-La Petite-Patrie).

\subsubsection{Identity: The Sense of Belonging to the Territory}

The majority of our respondents indicated having a strong sense of pride about living in their respective territory. In both boroughs, such a sentiment of pride has been manifested and reinforced through social struggles which constitute a mark for both districts. In Rosemont, it crystallized as part of the mobilization of citizens and local actors for the preservation of Cinéma Beaubien. In the Sud-Ouest, we observe a strong mobilization of the citizens motivated by the conversion of the former man- ufacturing facility of Canadian National Railways. The respondents displayed great pride in this collective project, named Bâtiment 7, which is still in progress but whose first achievements are already visible. In the same vein, in Rosemont we can point to the Technopôle Angus, a project initiated in the 1990s following the mobilization of the community, in particular the CDEC, with the aim of converting the brownfield left by the closing of the facility of the Canadian Pacific Railway.

Although the industrial past is a part of the identity that is shared by the inhabitants of both territories, it is more pronounced in the case of the Sud-Ouest, especially given the dominant presence of the Lachine Canal as a relic of this industrial past.

The Sud-Ouest was once home to the working class; it is a neighborhood that has contributed considerably to the making of what was once the industrial cradle of Canada, in the early twentieth century. All of these old factories and foundries, they're all a part of our industrial heritage, and I think people are quite attached to that. (Personal communication, municipal administration, Sud-Ouest)

You are in the most proud district of the city. People are very proud of their origins. People are very, very close to each other.... Historically, this area is a laboratory of sorts. This legacy of labor struggles still comes up, and invariably manifests in cultural expression, to make people feel proud. People are proud to be making a living by working. (Personal communication, community organization, Sud-Ouest)

\section{Discussion}

Let us recall here that we define cultural vitality not only by the presence on the territory of cultural facilities, creative enterprises and artists but also by the quality of the interactions between the cultural actors and between those from the other fields of local action (economic, social, environmental), as well as the anchoring of these relations into living environments.

In Rosemont, the cultural actors of the territory have managed to bring forth strong leadership at the borough level. This leadership is embodied by representatives of the RACRPP, which has a participative vision of culture. This leadership is recognized both by the municipal authorities of the borough, with whom there is a dialogue, and by the various cultural and socio-economic actors. With regard to governance, the indicators reveal several forms of coordination between actors. The borough council plays a role in the governance of cultural activities, although some respondents would like it to be equipped with more resources. At the same time, strong links between the cultural and community sectors have been observed. These links serve as a basis for building partnerships and support networks and can help to strengthen citizen participation in cultural events. Cul- 
tural elements have become cohesive identity markers. Accomplishments achieved through citizen action, such as those of the Technopôle Angus and Cinéma Beaubien, have reinforced a sense of belonging and pride that is part of an integrative institutional and organizational trajectory. This cohesion is favored by the physical morphology of the borough.

In the Sud-Ouest, leadership and cultural governance are being recomposed following the reconfiguration of local development actors as a consequence of the disappearance of the table of cultural actors and the weakening of RESO. The disappearance of the table highlights the increasing structuring role of neighborhoods and the loss of the role of the borough. However, some experiences enjoy the support of all stakeholders, such as Bâtiment 7 in Pointe-Saint-Charles. The initiative to convert this Canadian National Railways facility dates back quite some time and has been mobilizing the actors for over twenty years. These see it as an opportunity to turn a brownfield into an asset for the local community where cultural services and diverse community actions could take place. The reconversion, which is beginning to materialize, is a source of pride and hope. However, the research reveals that while cultural activities are important, collaboration between cultural, community and economic actors is still in need of being further developed in this borough, notwithstanding the willingness of municipal stakeholders to structure the cultural milieu. Moreover, the actors tend to work not at the borough level, which is an official level of government, but only at the neighborhood level, as a result of which they lack a common political interlocutor and opponent who could serve as a unifying force for them.

The two boroughs studied are therefore very active in terms of cultural and creative action. They are boroughs that, by and large, in 2018, are recovering well from the consequences of the major crisis experienced in the 1980s and the economic difficulties of the ensuing years. The boroughs' political bodies are aware of the importance of cultural activity, and organizations coordinate cultural interventions together with community actors. However, in both cases, citizens have not been that much engaged as cultural or artistic creators, instead limiting themselves to the consumption of activities or to citizen participation, thus, to being consumers, which weakens the innovative potential of cultural activity. The Bâtiment 7 project seems to mark a turning point in this regard, since the actors and citizens are engaged in designing and implementing the activities while also drawing benefit therefrom.

\section{Conclusion}

Proximity culture happens to be an important factor in the conversion of former industrial districts, not only with regard to cultural and creative activities but also local development as a whole. This rapprochement between creative and cultural action and community action is certainly one of the drivers of the socio-economic dynamics of these boroughs. We can say that the set of indicators of cultural vitality proposed in this article allows for a comprehensive as well as grounded assessment of a local cultural dynamic and the interactions between cultural actors and other local actors. At the same time, it allows to reveal a number of key factors in the structuring of a culture of proximity, in other words, factors that need to be considered when seeking to implement a public policy that is oriented towards proximity culture.

Our conclusions from the case study in Montreal can also be applied to other cities and places. Creative, artistic, and cultural activities can be used as a way to promote the expression of ideas from the most diverse groups and thereby begin to open up the deliberative processes traditionally dominated by political and economic elites, or even creative elites, such as those supported by the creative class theory.

Of course, there are cases when the promotion of cultural activities at the local level can have effects that do not contribute to the well-being of residents-the most notorious of which is gentrification. Nonetheless, many empirical studies show that it is possible to counteract the negative effects of gentrification. For the latter to happen, cultural initiatives need to be embedded within larger inclusionary strategies intended to improve both living and working conditions in local neighborhoods (Ghaffari, Klein, \& Angulo-Baudin, 2018). Those strategies must involve the residents and community actors, who should be part of culture-based strategies and participate as stakeholders in order to build fairer and more democratic cities.

\section{Acknowledgements}

This research was carried out in collaboration with the organizations Culture Montréal, Territoires innovants en économie sociale et solidaire (TIESS), the Centre for Research on Social Innovation (CRISES) and representatives of Montreal's artistic and creative agencies. It is part of a larger outreach project funded by the Social Sciences and Humanities Research Council of Canada (SSHRC Insight Program).

\section{Conflict of Interests}

The authors declare no conflict of interests.

\section{References}

André, I., \& Abreu, A. (2009). Social creativity and postrural places: The case of Montemor-o-Novo, Portugal. Canadian Journal of Regional Science, XXXII(1), 101-114.

Angulo-Baudin, W., Klein, J.-L., \& Tremblay, D.-G. (2017). Potencial y límites de las estrategias culturales de reconversión urbana: El caso de Bilbao [Potential and limits of cultural strategies of urban development: 
The case of Bilbao]. Finisterra. Revista Portuguesa de Geografia, LII(105), 49-78.

Auclair, E. (2011). Revenir vers les habitants, revenir sur les territoires [Inhabitants and places are back in town: Articulating culture and sustainability for local development]. Développement durable et territoires, 2(2). Retrieved from developpementdurable. revues.org/8946

Barbieri, N., Fina, X., \& Subirats, J. (2012). Culture and urban policies: Dynamics and effects of cultural third sector interventions in Barcelona. Métropoles, 11. Advanced online publication. Retrieved from journals.openedition.org/metropoles/4605

Bianchini, F., \& Landry, C. (1998). The creative city. London: Demos.

Chantelot, S. (2009). La thèse de la classe créative: Entre limites et développement [The creative class: Between limitations and developments]. Géographie, économie, société, 11, 315-334.

Crowe, S., Cresswell, K., Robertson, A., Huby, G., Avery, A., \& Sheikh, S. (2011). The case study approach. BMC Medical Research Methodology, 11(100), 2-9. Retrieved from www.biomedcentral.com/1471-2288/ $11 / 100$

Darchen, S., \& Tremblay, D.-G. (2013). The local governance of culture-led regeneration projects: A comparative analysis between Montreal and Toronto. Urban Research \& Practice, 6(2), 140-157.

Florida, R. (2002). The rise of the creative class and how it's transforming work, leisure, community and everyday life. New York, NY: Basic Books.

Fontan, J.-M., Klein, J.-L., \& Tremblay, D.-G. (2005). Innovation socioterritoriale et reconversion économique. Le cas de Montréal [Socio-territorial innovation and economic reconversion. The case of Montreal]. Paris: L'Harmattan.

Ghaffari, L., Klein, J.-L., \& Angulo-Baudin, W. (2018). For a socially acceptable gentrification: A survey of strategies and practices against displacement. Geography Compass, 12(2), 1-15. https://doi.org/ 10.1111/gec3.12355

Hamdouch, A., \& Depret, M.-H. (2009). Clusters, réseaux d'innovation et dynamique de proximité dans les secteurs high-tech [Clusters, innovation networks, and the dynamics of proximity in high-tech sectors]. Revue d'économie industrielle, 128, 21-52.

Karsten, L. (2009). From a top-down to a bottom-up urban discourse: (Re)constructing the city in a familyinclusive way. Journal of Housing and the Built Environment, 24, 317-329.

Klein, J.-L. (2017). Social innovation, universities and the quest for social transformation. In Higher education in the world 6. Towards a socially responsible university: Balancing the global with the local (pp. 165-178). Barcelona: Global University Network for Innovation (GUNI).

Klein, J.-L., \& Shearmur, R. (Eds.). (2017). Montréal: La cité des cités [Montreal, the city of neighborhoods].
Québec: Presses de l'Université du Québec.

Klein, J.-L., \& Tremblay, D.-G. (2016). Cultural creation and social innovations as the basis for building a cohesive city. In R. Shearmur, C. Carrincazeaux, \& D. Doloreux (Eds.), Geographies of innovation (pp. 447-462). Cheltenham: Edward Elgar.

Lefebvre, S. (2017). Le Quartier des spectacles: La mise en scène d'une centralité culturelle et festive [The Quartier des spectacles: The staging of a cultural and festive centrality]. In J.-L. Klein \& R. Shearmur (Eds.), Montréal: La cité des cités [Montreal, the city of neighborhoods] (pp. 193-208). Québec: Presses de I'Université du Québec.

Leriche, F., Daviet, S., Sibertin-Blanc, M., \& Zuliani, J.-M. (Eds.). (2008). L'économie culturelle et ses territoires [The cultural economy and its territories]. Toulouse: Presses universitaires du Mirail.

Markusen, A. (2006a). Cultural planning and the creative city. Paper presented at the Annual Meeting of the American Collegiate Schools of Planning, Fort Worth, Texas.

Markusen, A. (2006b). Building the creative economy for Minnesota's artists and communities. CURA Reporter, Summer, 7-25. Retrieved from http://hhh. oit.umn.edu/centers/prie/pdf/75_building_creative_ MN.pdf

Markusen, A. (2006c). Urban development and the politics of a creative class: Evidence from a study of artists. Environment and Planning A, 38, 1921-1940.

Markusen, A. (2008). Les artistes au cœur du développement urbain: Une approche par les métiers [Artists at the heart of urban development: An approach by trades]. In F. Leriche, S. Daviet, M. Sibertin-Blanc, \& J.-M. Zuliani (Eds.), L'économie culturelle et ses territoires [The cultural economy and its territories] (pp. 217-242). Toulouse: Presses universitaires du Mirail.

Markusen, A., \& Gadwa, A. (2010). Arts and culture in urban or regional planning: A review and research agenda. Journal of Planning Education and Research, 29(3), 379-391.

Martens, B., Dobbels, J., Amez, L., \& Ysebaert, W. (2014). Culture et créativité: Ébauche d'un instrument de mesure pour la métropole bruxelloise [Culture and creativity in the picture: design for a measurement tool for the Brussels metropolis]. Brussels Studies, 79. Advanced online publication. Retrieved from www.brusselsstudies.be

Mommaas, H. (2004). Cultural clusters and the postindustrial city: Towards the remapping of urban cultural policy. Urban studies, 41(3), 507-532.

Moulaert, F., Demuynck, H., \& Nussbaumer, J. (2004). Urban renaissance: From physical beautification to social empowerment. City, 8(2), 229-235.

Moulaert, F., MacCallum, D., Mehmood, A., \& Hamdouch, A. (2013). (Eds.). International handbook of social innovation: Collective action, social learning and transdisciplinary research. Cheltenham: Edward Elgar. 
Moulaert, F., \& Nussbaumer, J. (2008). Logique sociale du développement territorial [Social logic of territorial development]. Québec: Presses de I'Université du Québec.

Nadeau, G. (2009). Angus: Du grand capital à l'économie sociale [From big capital to the social economy]. Montréal: Fides.

Novy, A. (2013). Preliminary reflections on an eco-social civilization model for the 21st century. In J.-L. Klein \& M. Roy (Eds.), Pour une nouvelle mondialisation: Le défi d'innover [Toward a new globalization: The challenge of innovation] (pp. 211-324). Québec: Presses de l'Université du Québec.

Novy, A., Coimbra, D., \& Moulaert, F. (2012). Social cohesion: A conceptual and political elucidation. Urban Studies, 49(9), 1873-1889.

Peck, J. (2013). Social innovation...At the limits of neoliberalism. In J.-L. Klein \& M. Roy (Eds.), Pour une nouvelle mondialisation: Le défi d'innover [Toward a new globalization: The challenge of innovation] (pp. 11-30). Québec: Presses de I'Université du Québec.

Pilati, T., \& Tremblay, D.-G. (2007). Cité créative et District culturel; une analyse des thèses en présence [Creative city and cultural district: An analysis of existing theses]. Géographie, économie et société, 9, 381-401.

Pinçon, M. (1987). Désarrois ouvriers. Famille de métallurgistes dans les mutations industrielles et sociales [Disarray workers. Family of metallurgists in industrial and social changes]. Paris: L'Harmattan.

Poitras, C. (2017). L'axe du Canal de Lachine et les quartiers du Sud-Ouest: Grandeur et misère du berceau de l'industrialisation du pays [The axis of the Lachine Canal and the districts of the South-West: Greatness and misery of the cradle of industrialisation of the country]. In J.-L. Klein \& R. Shearmur (Eds.), Montréal: La cité des cites [Montreal, the city of neighborhoods] (pp. 193-208). Québec: Presses de l'Université du Québec.

RACRPP. (2018). Le RACRPP: Lorsque la force du nombre rime avec vitalité Culturelle. RACRPP. Retrieved from www.racrpp.org/a-propos

Rantisi, N. (2013). Revisiting contemporary accounts on the social basis of cultural production: Who is privileged? Who is sidelined? And what is at stake? Geoforum, 49, 9-11.

Rius, J., \& Sanchez-Belando, V. (2015). Modelo Barcelona y Política cultural: Usos y abusos de la cultura por parte de un modelo emprendedor de desarrollo local [Barcelona's model and cultural policy: The uses and abuses of culture by an enterprising local development model]. EURE, 41(122), 103-123.

Rius-Ulldemolins, J., \& Posso Jiménez, L. (2016). Cultura, transformación urbana y empoderamiento ciudadano frente a la gentrificación: Comparación entre el caso de Getsemaní (Cartagena de Indias) y el Raval (Barcelona) [Culture, urban transformation and citizen empowerment against gentrfication. Comparing the case of Getsemani (Cartagena de Indias) and El Raval (Barcelona)]. EURE, 42(126), 97-122.

Roy-Vallex, M. (2010). Ville attractive, ville créative: La plus-value de la culture au regard des "créatifs" du jeu vidéo à Montréal [Attractive city, creative city: The added value of culture with regard to the "creatives" of video game in Montreal] (Unpublished Doctoral dissertation). Institut National de la Recherche Scientifique, Montreal.

Sacco, P.-L., Blessi, G., \& Nuccio, M. (2008). Culture as an engine of local development processes: Systemwide cultural districts. Growth and Change, 44(4), 555-570.

Santagata, W. (2006). Cultural district and economic development (EBLA Working Paper). Turin: University of Turin.

Scott, A. J. (2010). L'économie culturelle et le champ créatif de la ville [The cultural economy and the creative field of the city]. In P. Cary \& A. Joyal (Eds.). Penser les territoires [Thinking out territories] (pp. 197-226). Québec: Presses de I'Université du Québec.

Shearmur, R. (2010). L'aristocratie du savoir et son tapis rouge. Quelques réflexions sur les thèses de Richard Florida [The aristocracy of knowledge and its red carpet. Some thoughts on Richard Florida's theories]. In D.-G. Tremblay \& R. Tremblay (Eds.), La compétitivité urbaine à l'ère de la nouvelle économie: Enjeux et défis [Urban competitiveness in the era of the new economy: Issues and challenges] (pp. 285-303). Québec: Presses de l'Université du Québec.

Sibertin-Blanc, M. (2008). La culture dans l'action publique des petites villes. Un révélateur des politiques urbaines et recompositions territoriales [Cultural actions in small towns: An indicator of urban policies and territorial dynamics]. Géocarrefour, 83(1), 5-13.

Sibertin-Blanc, M. (2009). Cultures et projet(s) de territoire [Cultures and territorial project(s)]. Sud-Ouest européen. Advanced online publication. Retrieved from journals.openedition.org/soe/1960

Swyngedouw, E., Moulaert, F., \& Rodriguez, A. (2002). Neoliberal urbanization in Europe: Large-scale urban development projects and the new urban policy. Antipode, 34(3), 542-577.

Tremblay, D.-G., \& Darchen, S. (2010). La thèse de la classe créative: Revue des écrits et perspectives de recherche [Creative Class theory: A review of writings and research perspectives], In R. Tremblay \& D.G. Tremblay (Eds.), La classe créative selon Richard Florida: Un paradigme urbain plausible? [The creative class according to Richard Florida: A plausible urban paradigm] (pp. 13-35). Québec: Presses de l'université du Québec et Presses universitaires de Rennes.

Tremblay, R., \& Tremblay, D.-G. (2010). La classe créative selon Richard Florida: Un paradigme urbain plausible? [The creative class according to 
Richard Florida: A plausible urban paradigm] Québec, Rennes: Presses de l'université du Québec, Presses universitaires de Rennes.

Ville Montreal. (n.d.). Annuaire statistiques de l'agglomération de Montréal [Statistics directory of Greater Montreal]. Ville Montreal. Retrieved from ville.montreal.qc.ca/portal/page?_pageid $=6897,681$ 49701\&_dad=portal\&_schema=PORTAL

Vivant, E. (2007). L'instrumentalisation de la culture dans les politiques urbaines: Un modèle d'action transposable? [Is the instrumentalization of culture in urban policy a transposable model?]. Espaces et société, 131, 49-66.

Wetherell, S. (2017). Richard Florida is sorry. Jacobin. Retrieved from jacobinmag.com/2017/08/new-urbancrisis-review-richard-florida

Yin, R.-K. (2009). Case study research: Design and methods (4th ed.). Thousand Oaks, CA: SAGE.

\section{About the Authors}

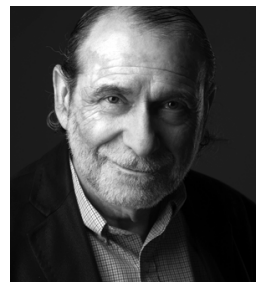

Juan-Luis Klein is a Full Professor at the University of Quebec at Montreal and the former director of the Centre de recherche sur les innovations sociales (crises.uqam.ca). His research projects are on socioterritorial innovation, and community revitalization. He assumes several duties in editorial committees of scientific journals and is the director of the Géographie Contemporaine Series. He is currently co-president of a nongovernmental organization for knowledge transfer in social innovation, social economy, and territorial development (www.tiess.ca).

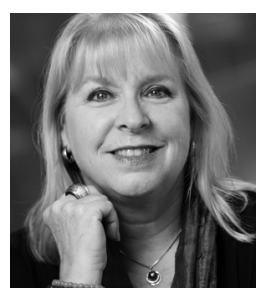

Diane-Gabrielle Tremblay is Professor of Labour Economics, Innovation and Human Resources Management at Téluq, Canada. She was appointed Canada Research Chair on the socioeconomic challenges of the Knowledge Economy in 2002 (www.teluq.uquebec.ca/chaireecosavoir) and again in 2009-2016, and appointed director of a Community-University Research Alliance (CURA) on the management of social times and work-life balance in 2009 (benhur.teluq.uquebec.ca/SPIP/ aruc/spip.php?article2). She has created a program on Management of Creative Projects and she has been an invited professor in many European universities.

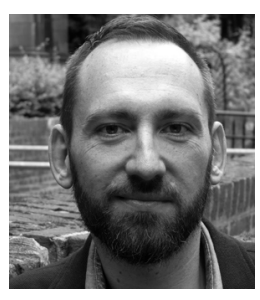

Laurent Sauvage has graduated in Art History and Political Science. After a career in various cultural institutions (museums, music companies and festivals), he is currently a PhD student in urban studies at the University of Quebec at Montreal. Under the co-direction of Juan-Luis Klein and Diane-Gabrielle Tremblay, he works on the mobilization of culture in the integrated urban revitalization operations in Montreal.

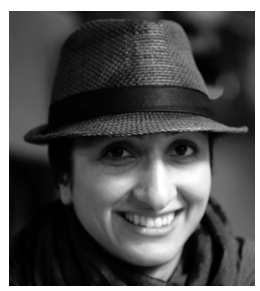

Leila Ghaffari is mostly interested in urban issues related to social justice in local development. Her research is related to urban studies and urban planning areas. Gentrification is the focus of her current studies. She has authored and coauthored articles and book chapters on local development of small- and medium-sized towns and also on gentrification. She is currently a PhD candidate of a joint program at University of Quebec at Montreal and University of François Rabelais of Tours, France.

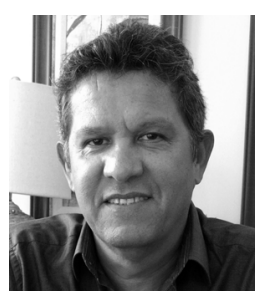

Wilfredo Angulo is a former Professor in the Department of Geography and History at Pedagogical Institute of Caracas. After having a PhD at the University of Montpellier III, he is currently a PhD candidate in Urban Studies at the University of Quebec, Montreal (UQAM), and a research assistant at CRISES. His research projects focus on urban revitalization, and social exclusion. He has written and cowritten articles and book chapters on local development through culture and community intervention. 